
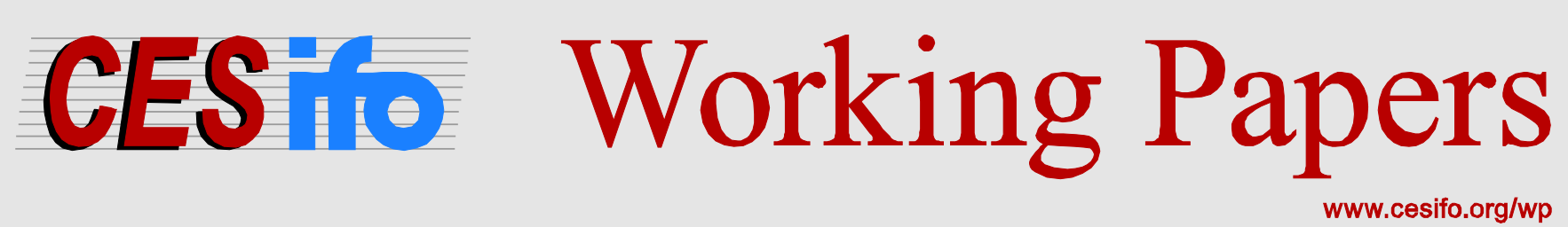

\title{
Statures, BMIs, and Weight: A Reassessment
}

\author{
Scott Alan Carson
}

\author{
CESIFO WORKING PAPER NO. 4540 \\ CATEGORY 4: LABOUR MARKETS \\ DECEMBER 2013
}

An electronic version of the paper may be downloaded

- from the SSRN website:

- from the RePEc website:

- from the CESifo website:

wWw.SSRN.com

Www.RePEc.org

www.CESifo-group.org/wp

\section{CESifo}




\title{
Statures, BMIs, and Weight: A Reassessment
}

\begin{abstract}
Much has been written about the modern obesity epidemic, and historical BMIs are low compared to their modern counterparts. However, interpreting BMI variation is difficult because BMIs increase when weight increases or when stature decreases, and the two have different implications for human health. An alternative measure for net current biological conditions is body weight. After controlling for height, African-American and white weights decreased throughout the late 19th and early 20th centuries. Farmers had greater average weights than workers in other occupations. Individuals from the South had taller statures, greater BMIs, and heavier weights than workers in other US regions, indicating that even though the South had higher 19th century disease rates, it had better net nutritional conditions.
\end{abstract}

JEL-Code: I100, J110, J150, N000, N310.

Keywords: anthropometrics, nineteenth century US weights, net nutrition, health.

Scott Alan Carson

University of Texas, Permian Basin

4901 East University

USA - Odessa, TX 79762

Carson_S@utpb.edu

I appreciate comments from John Komlos, Gary Taubes, Doug Henderson, Joe Beane, and Paul Hodges. 
A Weighty Issue: Diminished $19^{\text {th }}$ Century Net Nutrition among the US Working Class

\section{Introduction}

It is now well accepted that a population's average stature measures the net cumulative difference between nutrition and calories consumed for work and to fend off disease (Deaton, 2008; Case and Paxon, 2008a; Case and Paxson, 2008b). Similarly, the body mass index (BMI) is interpreted to represent the net current difference between the same variables (Fogel, 1994). However, as the ratio of weight to height, BMI does not fully isolate net current nutrition because weight in the numerator represents net current nutrition, while height in the denominator reflects net cumulative conditions, and this complicates the meaning of BMI declines over time (Fogel, 1994; Strauss and Thomas, 1998, p. 773; Komlos and Brabec, 2010). ${ }^{1}$ Moreover, recent studies call into question the meaning of the late $19^{\text {th }}$ and early $20^{\text {th }}$ century stature decline because US BMIs may have increased at the same time that average statures and weight declined (Komlos, 1987; Costa and Steckel, 1997, pp. 50-55; Carson, 2009a; Komlos and Brabec, 2010). An alternative biological measurement for net current nutritional conditions is body weight, after controlling for height. Total weight increases when nutrition improves, and taller heights can accommodate greater weight; however, BMIs are inversely related with statures because taller statures allow weight to be distributed over greater physical dimensions (Herbert, et al., 1993 p.

${ }^{1} \mathrm{BMI}=\frac{\text { Weight }(\text { Kg. })}{(\text { Height }(\mathrm{Mt} .))^{2}}$ 
1438; Carson, 2009a). ${ }^{2}$ Since weight varies more than stature with present conditions, weightafter controlling for height—provides important insight into how net current nutrition varies over time, across ethnic groups, and across socioeconomic status. This seeming paradox is resolved by examining weight and height variation in isolation. ${ }^{3}$

Health and net nutrition were compromised during $19^{\text {th }}$ century US industrialization and urbanization when food production was separated from food consumption (Komlos, 1985; Komlos, 1987; Haines, 2004; Floud et al., 2011, pp. 311-302; Carson, 2008a). Despite its importance relative to other physical measurements, weight has received little attention in historical health studies, which is due mostly to a lack of data. Two existing studies that address $19^{\text {th }}$ century US weights are Komlos (1987) and Komlos and Coclanis (1995). Using $19^{\text {th }}$ century West Point cadet records, Komlos (1987) shows a general decline in net nutrition that was geographically widespread and affected blue-collar worker and farmer weights. Socioeconomic status and nutrition are related, and middle class Cadets were not as vulnerable to

\footnotetext{
${ }^{2}$ If an individual receives sufficient net nutrition during their youth, they reach taller statures, and their BMIs may be shorter as they age because their frames have more surface area to distribute weight. In sum, average stature is an easier measure to interpret than BMI because stature measures the net cumulative difference between calories consumed and expended for work and to fend off disease but may not isolate how net current biological conditions vary.

${ }^{3}$ Interpreting BMIs is more difficult than interpreting stature because BMI is the ratio of height in kilograms divided by weight in meters squared, therefore, is the ratio of net current to net cumulative nutrition. Statures and BMIs are also sensitive to early life conditions. For example, as a function of weight and height, if a person receives insufficient nutrition as a youth, their statures may be shorter, their frames smaller, and their basal metabolic needs will be low in later life. If their nutrition improves as they get older, their BMIs are more likely to be high because their frames have less surface area to distribute weight (Herbert et al., 1993, p. 1438; Ravelli et al., 1976; Baum and Ruhm, 2009).
} 
nutrition declines until the Civil War. Nutritional status may have also declined because meat and animal protein production decreased when population growth, urbanization, and industrialization increased the demand for food. Reinforcing this trend, late $19^{\text {th }}$ and early $20^{\text {th }}$ century students at The Citadel's average weight decreased between 1880 and 1900 (Coclanis and Komlos, 1995, p. 104), which indicates that net current nutrition declined throughout the late $19^{\text {th }}$ century. Nineteenth century weight studies have, otherwise, gone without notice.

It is against this backdrop that this study considers three paths of inquiry into the relationship between historical US weights, demographics, and socioeconomic characteristics during the early stages of economic growth. First, how did weight and height vary by race over the late $19^{\text {th }}$ and early $20^{\text {th }}$ centuries? Black and white weight and height decreased throughout the century, and there is no sign that average weights or obesity increased among the working class prior to the modern obesity epidemic. Second, how did weight vary with respect to occupations and socioeconomic status? Consistent with stature and BMI studies, farmers and unskilled workers had heavier weights and better net nutrition than white-collar and skilled workers. Third, what was the relationship between weight and residence? Diets and physical activity varied regionally, and after controlling for height, individuals in the West and Deep South had greater body weight than individuals from the Middle Atlantic, Northeast, and Upper South.

\section{Nineteenth Century US Prisons and Weight Variation}

To separate how weight and height varied over the late $19^{\text {th }}$ and early $20^{\text {th }}$ centuries requires a reliable data set, and the two most common sources for historical weight and height data are military and prison records. One common shortfall of military records that may be related to weights is a stature requirement for military service, and arbitrarily truncating shorter 
statures may underestimate weights because shorter people are more likely to have heavier weights; however, only taller individuals with lower BMIs remain in military records (Herbert et al., 1993, p. 1438; Carson, 2009a). Fortunately, prison records do not suffer from such a constraint and the subsequent truncation bias observed in military samples. Nevertheless, because they may have selected many of the materially poorest individuals, prison records are not above reproach and it is not clear which portion of the socioeconomic strata prisoners represent. For example, skilled and white-collar workers were imprisoned for fraud and embezzlement, which represents conditions among the upper class, while unskilled workers were imprisoned for assault and theft crimes, which represent conditions among the working class. Because, the majority of prisoners were incarcerated for assault and theft crimes, prison records represent conditions among the working class, that segment of society most sensitive to economic change. There is also little evidence that there was a consistent relationship between weight, height, and the type of crime for which an individual was incarcerated (Carson, 2005, p. 414; Carson, 2007, p. 44). 
Table 1, Nineteenth Century US State Penitentiaries

\begin{tabular}{l|cccc}
\hline Prison & Black & \multicolumn{3}{l}{ White } \\
\hline & $N$ & Percent & $N$ & Percent \\
Arizona & 194 & .29 & 2,156 & 2.93 \\
Colorado & 483 & .71 & 3,502 & 4.76 \\
Idaho & 36 & .05 & 575 & .78 \\
Kentucky & 6,167 & 9.09 & 6,602 & 8.97 \\
Missouri & 4,292 & 6.33 & 7,984 & 10.85 \\
New Mexico & 344 & .51 & 1,993 & 2.71 \\
Oregon & 45 & .07 & 1,683 & 2.29 \\
Pennsylvania & 2,685 & 3.96 & 11,214 & 15.24 \\
Philadelphia & 5,481 & 8.08 & 11,410 & 15.51 \\
Tennessee & 20,940 & 30.88 & 10,384 & 14.11 \\
Texas & 27,154 & 40.04 & 16,083 & 21.85 \\
Total & 67,821 & 100.00 & 73,586 & 100.00 \\
\hline
\end{tabular}

Source: All state prison repositories were contacted and available records were acquired and entered into a master data set. These prison records include Arizona, California, Colorado, Idaho, Illinois, Kansas, Kentucky, Missouri, Montana, Nebraska, New Mexico, Ohio, Oregon, Pennsylvania, Texas, and Washington.

The data used here is part of a large $19^{\text {th }}$ century prison sample. Most blacks in the sample were imprisoned in Border States and Deep South, such as Kentucky, Missouri, and Texas. Most whites in the sample were imprisoned in Missouri and Texas, but Northern whites were also from Pennsylvania and the Far West (Table 1). Between 1840 and 1920, prison officials regularly recorded the dates inmates were received, pre-incarceration occupation, weight, height, nativity, complexion, and age. Physical descriptions were recorded by prison enumerators at the time of incarceration as a means of identification, therefore, reflect preincarceration conditions. All records with complete age, weight, height, occupations, and nativity are used for this study. Because accurate recordings had legal implications for 
identification in the case that inmates escaped and were later recaptured, there was care in recording inmate heights and weights. Arrests and prosecutions across states may represent various selection biases that may affect the results of this analysis. However, black and white stature variations across US prisons are consistent with other historical height studies (Steckel, 1979; Margo and Steckel, 1982; Margo and Steckel, 1992). Because there are too few females in the sample and the purpose of this study is US male health conditions, females and immigrants are excluded from this analysis. ${ }^{4}$

Enumerators recorded a diverse set of occupations but defined them narrowly, recording over 200 different occupations, which are classified here into four categories: laborers and miners are classified as unskilled workers. Unfortunately, prison enumerators did not always distinguish between farm and common laborers. Since common laborers probably encountered less favorable biological conditions, this may overestimate the biological benefits of being a common laborer and underestimate the advantages of being a farm laborer (Carson, 2013, pp. 62-63). Workers in the agricultural sector are classified as farmers; light manufacturing, craft workers, and carpenters are classified as skilled workers; merchants and high skilled workers are classified as white-collar workers.

Inmate enumerators were thorough when recording inmate complexions. For example, enumerators recorded inmates' race in a complexion category and recorded white complexions as light, fair, medium, and dark. This white inmate complexion classification is also supported

\footnotetext{
${ }^{4}$ All state prison repositories were contacted and available records were acquired and entered into a master data set. These prison records include Arizona, California, Colorado, Idaho, Illinois, Kansas, Kentucky, Missouri, Montana, Nebraska, New Mexico, Ohio, Oregon, Pennsylvania, Texas, and Washington (Table 1). Female statures are examined elsewhere (Carson, 2011; Carson, 2013a).
} 
by European immigrant complexions who were always recorded with fair complexions as light, medium, and dark. African-Americans were recorded as black, light-black, dark-black, and assorted shades of mulatto. While mulatto inmates shared genetic traits with both European and African ancestry, they were treated as blacks in the $19^{\text {th }}$ century, and when comparing whites to blacks, mulattos are grouped here with blacks (Carson, 2009b). 
Table 2, Nineteenth Century Black and White Weights and Heights by Demographics, Birth

Period, and Occupations

\begin{tabular}{|c|c|c|c|c|c|c|c|c|}
\hline & \multicolumn{3}{|c|}{ Blacks } & \multicolumn{5}{|c|}{ White } \\
\hline Ages & $\mathrm{N}$ & $\%$ & Weight & Height & $\mathrm{N}$ & $\%$ & Weight & Height \\
\hline Teens & 14,044 & 20.71 & 140.08 & 65.99 & 10,035 & 13.64 & 137.75 & 66.77 \\
\hline $20 s$ & 36,128 & 53.27 & 152.89 & 67.24 & 36,607 & 49.75 & 146.59 & 67.64 \\
\hline $30 s$ & 11,074 & 16.33 & 154.95 & 67.30 & 16,191 & 22.00 & 148.55 & 67.58 \\
\hline $40 \mathrm{~s}$ & 4,216 & 6.22 & 155.07 & 67.07 & 6,841 & 9.30 & 149.71 & 67.43 \\
\hline $50 \mathrm{~s}$ & 1,678 & 2.47 & 154.44 & 66.87 & 2,841 & 3.86 & 149.90 & 67.34 \\
\hline $60 s$ & 557 & .82 & 152.81 & 66.70 & 896 & 1.22 & 147.91 & 67.18 \\
\hline $70 \mathrm{~s}$ & 124 & .18 & 146.89 & 66.18 & 175 & .24 & 148.31 & 66.86 \\
\hline \multicolumn{9}{|l|}{ Decade } \\
\hline \multicolumn{9}{|l|}{ Received } \\
\hline $1840 s$ & 20 & .03 & 163.6 & 69.21 & 165 & .22 & 158.97 & 69.04 \\
\hline $1850 \mathrm{~s}$ & 55 & .08 & 155.07 & 67.35 & 839 & 1.14 & 149.13 & 68.22 \\
\hline $1860 \mathrm{~s}$ & 980 & 1.44 & 150.10 & 66.37 & 1,307 & 1.78 & 148.95 & 67.75 \\
\hline $1870 \mathrm{~s}$ & 7,615 & 11.23 & 152.61 & 66.94 & 8,748 & 11.89 & 144.36 & 67.37 \\
\hline $1880 \mathrm{~s}$ & 12,508 & 18.44 & 151.99 & 67.26 & 10,888 & 14.80 & 146.32 & 67.47 \\
\hline $1890 \mathrm{~s}$ & 14,285 & 21.06 & 150.99 & 66.93 & 14,114 & 19.18 & 147.51 & 67.56 \\
\hline $1900 \mathrm{~s}$ & 16,319 & 24.06 & 149.52 & 66.76 & 17,782 & 24.16 & 145.68 & 67.23 \\
\hline $1910 \mathrm{~s}$ & 15,090 & 22.25 & 149.87 & 67.01 & 18,533 & 25.19 & 146.23 & 67.61 \\
\hline 1920s & 949 & 1.40 & 150.34 & 66.86 & 1,210 & 1.64 & 147.05 & 67.62 \\
\hline \multicolumn{9}{|l|}{ Residence } \\
\hline Arizona & 194 & .29 & 151.76 & 67.56 & 2,156 & 2.93 & 147.36 & 67.41 \\
\hline Colorado & 483 & .71 & 154.43 & 67.15 & 3,502 & 4.76 & 150.26 & 67.40 \\
\hline Idaho & 36 & .05 & 152.63 & 67.04 & 575 & .78 & 150.06 & 68.06 \\
\hline Kentucky & 6,167 & 9.09 & 147.55 & 66.65 & 6,602 & 8.97 & 145.79 & 67.75 \\
\hline Missouri & 4,292 & 6.33 & 145.63 & 66.72 & 7,984 & 10.85 & 142.66 & 67.50 \\
\hline New Mexico & 344 & .51 & 154.46 & 67.55 & 1,993 & 2.71 & 150.27 & 67.89 \\
\hline Oregon & 45 & .07 & 155.57 & 66.63 & 1,683 & 2.29 & 151.82 & 67.23 \\
\hline Pennsylvania & 2,685 & 3.96 & 147.80 & 66.32 & 11,214 & 15.24 & 145.10 & 66.67 \\
\hline Philadelphia & 5,481 & 8.08 & 146.42 & 66.22 & 11,410 & 15.51 & 140.83 & 66.57 \\
\hline Tennessee & 20,940 & 30.88 & 150.32 & 66.56 & 10,384 & 14.11 & 148.36 & 67.61 \\
\hline Texas & 27,154 & 40.04 & 153.62 & 67.58 & 16,083 & 21.86 & 149.30 & 68.42 \\
\hline \multicolumn{9}{|l|}{ Occupations } \\
\hline White Collar & 1,747 & 2.58 & 149.06 & 66.81 & 7,024 & 9.55 & 145.90 & 67.36 \\
\hline Skilled & 5,147 & 7.59 & 151.03 & 66.97 & 16,395 & 22.28 & 145.96 & 67.85 \\
\hline Farmers & 6,411 & 9.45 & 154.38 & 67.54 & 7,307 & 9.93 & 150.08 & 68.20 \\
\hline Unskilled & 38,551 & 56.84 & 150.87 & 67.08 & 32,289 & 43.88 & 146.30 & 67.50 \\
\hline No & 15,965 & 23.54 & 149.04 & 66.45 & 10,571 & 14.37 & 144.17 & 67.25 \\
\hline \multicolumn{9}{|l|}{ Occupations } \\
\hline Total & 67.821 & 100.00 & & & 73,586 & 100.00 & & \\
\hline
\end{tabular}

Source: See Table 1. 
Table 2 presents black and white inmates’ weight and height by age, observation period, residence, and occupations. Although average weights and heights are included, they are not reliable because of possible compositional effects, which are accounted for in the regression models in a later section. Blacks were a smaller portion of the prison population than whites; 48 percent of the US prison population is black. However, blacks are over represented in the prison sample compared to the general population. Age percentages demonstrate that black inmates were incarcerated at younger ages, and whites were incarcerated at older ages (Hirschi and Gottfredson, 1983). During the early $19^{\text {th }}$ century, slaves were less likely to be incarcerated because Southern planters lost money when their slaves were imprisoned (Wahl, 1996; Wahl, 1997). The result was that Southern law evolved to allow planters to punish their slaves who broke the law on their plantations, where slaves worked for their masters while paying the social costs of their crimes. Blacks were more likely to be incarcerated after passage of the $13^{\text {th }}$ Amendment. Whites were more likely to be from Northern and Far Western states; blacks were more likely to be from the South. Whites were more likely to be white-collar, skilled workers, and farmers. Blacks were more likely to be unskilled.

III. Changing Body Mass, Obesity, and Health

To highlight the importance of $19^{\text {th }}$ century weight variation, BMIs illustrate how net current nutritional status may have varied throughout the late $19^{\text {th }}$ and early $20^{\text {th }}$ centuries. The World Health Organization’s (WHO) BMI coding system provides thresholds for weight and obesity classifications, and individuals with BMIs less than 18.5 are underweight; BMIs 
between 18.5 and 24.9 are normal; BMIs between 24.9 and 29.9 are overweight; BMIs greater than 29.9 are obese. $^{5}$

Figure 1 Nineteenth century US Black and White BMI Distributions and Overtime.
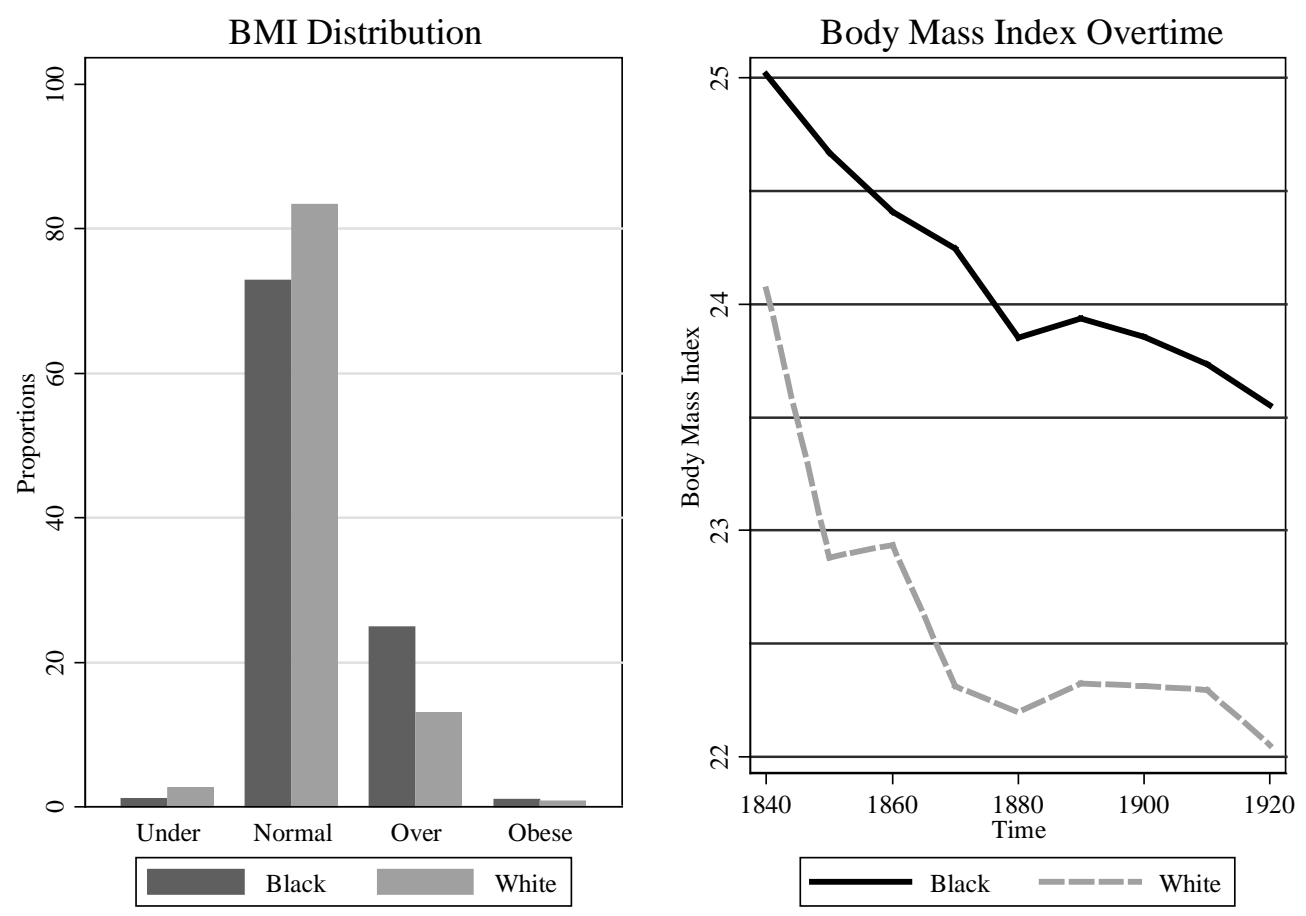

Source: See Table 1 and 3.

Figure 1 demonstrates that the majority of $19^{\text {th }}$ century US black and white BMIs were in the normal category and neither obesity nor starvation were common (Carson, 2009a; Carson, 2012a). Average black youth and adult BMIs were 23.03 and 24.07, respectively; average white youth and adult BMIs were 21.96 and 22.78. It is also noteworthy that proportionally so few

\footnotetext{
${ }^{5}$ Henderson (2005) demonstrates that these BMI thresholds may have shifted right between the $19^{\text {th }}$ and early $20^{\text {th }}$ centuries.
} 
blacks and whites fell into the underweight and obese categories, indicating that $19^{\text {th }}$ century black and white net nutritional conditions were not at privation (Flogel, 1994; Fogel, 2004, p. 11). Costa and Steckel (1997, pp. 50-55) indicate that BMIs likely increased during the second half of the $19^{\text {th }}$ century. To the degree that BMIs represent net current access to calories relative to work effort, black and white BMIs declined throughout the $19^{\text {th }}$ century, which, like stature, indicates that net nutrition declined with the separation of food production from food consumption (Carson, 2008a). In sum, black and white BMIs were in normal categories, and net dietary stress increased throughout the late $19^{\text {th }}$ and early $20^{\text {th }}$ centuries among the working class. Measuring weight and height separately illustrates the effects of how observable characteristics were related with changing weight versus changing stature. Moreover, weight studies address lingering questions in stature and BMI studies because if $19^{\text {th }}$ century weight decreased after accounting for height, it indicates that net current nutrition declined with the separation of food production and food consumption. 
Figure 2 Nineteenth Century Black and White Weight Distributions

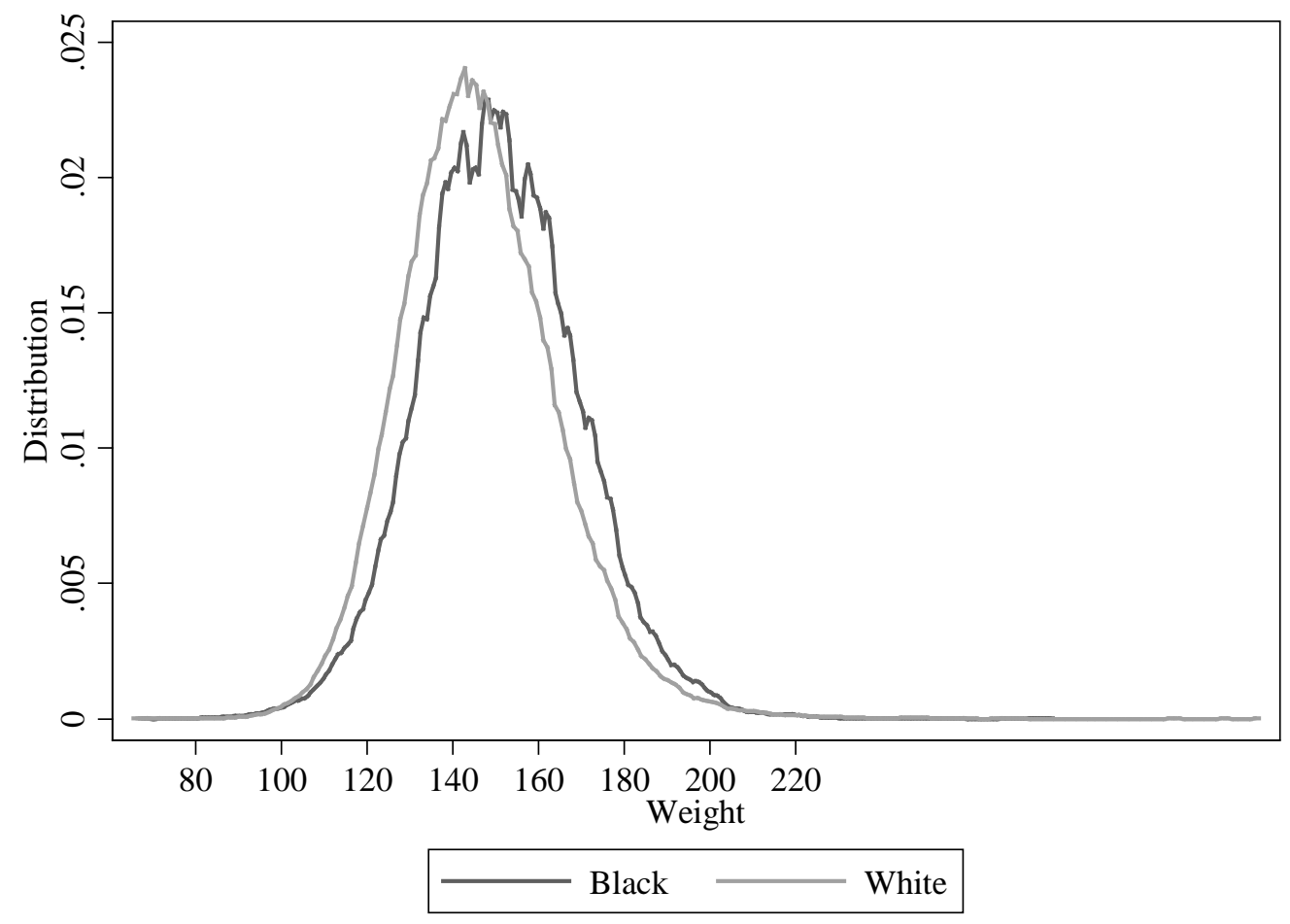

Source: See Table 1.

How weight was distributed provides insight into a population's health, and if weight is positively skewed, individuals in a population are underweight. If the weight distribution is negatively skewed, a population is overweight or obese. Figure 2 presents black and white weight kernel density estimates and illustrates that black and white weights were approximately symmetric and that late $19^{\text {th }}$ and early $20^{\text {th }}$ century men were neither starved nor lived in caloric excess. Average black weight was 150.74 pounds, and average black height was 66.96 inches. Average white weight was 146.26 pounds, and average white height was 67.47 inches.

However, heavier $19^{\text {th }}$ century black weights are not necessarily a sign of superior net nutrition 
because blacks were short and heavy, while whites were tall and thin (Margo and Steckel, 1982; Herbert et al. 1993, p. 1436; Carson, 2009a; Carson, 2012a).

IV. The Relative Effects of Race, Age, Nativity, and Socioeconomic Conditions with

$$
\text { Weight }
$$

The timing and extent of weight variation reflects the net current relationship between diets, disease, socioeconomic status, and residence. We test which of these variables were associated with late $19^{\text {th }}$ and early $20^{\text {th }}$ century weight variation. To start, the weight of the $i^{\text {th }}$ individual is assumed to be a function of height, race, demographics, observation period, residence, and occupations.

$$
\begin{gathered}
\text { Weight }_{\mathrm{i}}=\alpha+\beta_{1} \text { Inches }_{\mathrm{i}}+\sum_{\mathrm{r}=1}^{2} \beta_{\mathrm{r}} \text { Race }_{\mathrm{i}}+\sum_{\mathrm{a}=1}^{14} \beta_{\mathrm{a}} \text { Age }_{\mathrm{i}}+\sum_{\mathrm{b}=1}^{8} \beta_{\mathrm{b}} \text { Decade Re ceived }_{\mathrm{i}} \\
+\sum_{\mathrm{p}=1}^{10} \beta_{\mathrm{p}}{\text { Re } \text { sidence }_{\mathrm{i}}}+\sum_{\mathrm{j}=1}^{4} \beta_{\mathrm{j}} \text { Occupation }_{\mathrm{i}}+\varepsilon_{\mathrm{i}}
\end{gathered}
$$

A continuous height variable is included to account for the relationship between weight and height. Black and mulatto race dummy variables are included to measure the relationship between weight and skin complexion. Dummy variables are included for ages between 14 and 22; adult decade age dummy variables are included for ages 30 through 70 . Decade received dummy variables are included to account for how net current conditions varied by observation period. Residence dummy variables account for the relationship between weight and the physical environment. Occupation dummy variables are included to account for how weight was related with socioeconomic status. 
To estimate the relationship between weight, height, and observable characteristics, Table 3’s Models 1 and 2 include all black and white observations. Models 3 and 4 present estimates for black weight and height, and Models 5 and 6 do the same for whites.

Table 3 Nineteenth Century Black and White Heights and Weights by Demographics,

Socioeconomic Status, and Location

\begin{tabular}{|c|c|c|c|c|c|c|}
\hline & Total & & Blacks & & Whites & \\
\hline & $\begin{array}{l}\text { Model } 1 \\
\text { Weight }\end{array}$ & $\begin{array}{c}\text { Model } 2 \\
\text { Height }\end{array}$ & $\begin{array}{l}\text { Model } 3 \\
\text { Weight }\end{array}$ & $\begin{array}{c}\text { Model } 4 \\
\text { Height }\end{array}$ & $\begin{array}{l}\text { Model } 5 \\
\text { Weight }\end{array}$ & $\begin{array}{c}\text { Model } 6 \\
\text { Height }\end{array}$ \\
\hline $\begin{array}{l}\text { Intercept } \\
\text { Height }\end{array}$ & $-88.21 * * *$ & $44.78^{* * *}$ & $-75.69 * * *$ & $51.26 * * *$ & $-94.48 * * *$ & $43.78 * * *$ \\
\hline $\begin{array}{l}\text { Inches } \\
\text { Race }\end{array}$ & $3.47^{* * *}$ & & $3.41^{* * *}$ & & $3.54^{* * *}$ & \\
\hline White & Reference & Reference & & & & \\
\hline Black & $7.34 * * *$ & $-.927 * * *$ & Reference & Reference & & \\
\hline $\begin{array}{l}\text { Mulatto } \\
\text { Ages }\end{array}$ & $4.98^{* * *}$ & $-.645 * * *$ & $-2.22 * * *$ & $.276^{* * *}$ & & \\
\hline 14 & $-19.40 * * *$ & $-4.57 * * *$ & $-21.10 * * *$ & $-4.51 * * *$ & $-13.60 * * *$ & $-4.94 * * *$ \\
\hline 15 & -16.90 *** & $-3.22 * * *$ & $-18.76^{* * *}$ & $-3.18 * * *$ & $-12.71 * * *$ & $-3.40 * * *$ \\
\hline 16 & $-13.23 * * *$ & $-2.09 * * *$ & $-14.73^{* * *}$ & $-2.02 * * *$ & $-10.77^{* * *}$ & $-2.04 * * *$ \\
\hline 17 & $-9.69 * * *$ & $-1.29 * * *$ & $-10.87 * * *$ & $-1.31 * * *$ & $-8.28 * * *$ & $-1.25^{* * *}$ \\
\hline 18 & $-7.28 * * *$ & $-.809 * * *$ & $-8.44 * * *$ & $-.889 * * *$ & $-5.94 * * *$ & $.693^{* * *}$ \\
\hline 19 & $-4.72 * * *$ & $-.474 * * *$ & $-5.65^{* * *}$ & $-.537 * * *$ & $-3.80 * * *$ & $-.393 * * *$ \\
\hline 20 & $-3.13 * * *$ & $-.195 * * *$ & $-3.80 * * *$ & $-.215 * * *$ & $-2.49 * * *$ & $-.170 * * *$ \\
\hline 21 & $-1.93 * * *$ & $-.093 * * *$ & $-2.23 * * *$ & $-.139 * * *$ & $-1.85 * * *$ & -.043 \\
\hline 22 & $-1.22 * * *$ & $-.057 * *$ & $-1.35 * * *$ & $-.092 * *$ & $-1.18 * * *$ & -.022 \\
\hline $23-29$ & Reference & Reference & Reference & Reference & Reference & Reference \\
\hline $30 \mathrm{~s}$ & $1.37 * * *$ & $-.068 * * *$ & $1.37 * * *$ & -.005 & $1.46^{* * *}$ & $-.109 * * *$ \\
\hline 40s & $2.73^{* * *}$ & $-.351 * * *$ & $2.04 * * *$ & $-.322 * * *$ & $3.18^{* * *}$ & $-.349 * * *$ \\
\hline 50s & $2.93^{* * *}$ & $-.680 * * *$ & $1.79 * * *$ & $-.664 * * *$ & $3.64 * * *$ & $-.641 * * *$ \\
\hline 60s & $1.50^{* * *}$ & $-.985 * * *$ & .461 & $-.906 * * *$ & $2.09 * * *$ & $-.968^{* * *}$ \\
\hline $70 \mathrm{~s}$ & .653 & $-1.57 * * *$ & $-3.74 * * *$ & $-1.50 * * *$ & $3.83 * *$ & $-1.49 * * *$ \\
\hline Birth Decade & & & & & & \\
\hline 1800 & & $1.24^{* * *}$ & & $.759 *$ & & $1.32^{* * *}$ \\
\hline 1810 & & $1.10^{* * *}$ & & $.769 * * *$ & & $1.21^{* * *}$ \\
\hline 1820 & & $.780^{* * * *}$ & & $.306^{* *}$ & & $.996^{* * *}$ \\
\hline 1830 & & $.280^{* * *}$ & & .059 & & $.384^{* * *}$ \\
\hline 1840 & & $.160^{* * *}$ & & .057 & & $.227^{* * *}$ \\
\hline 1850 & & $.078^{* * *}$ & & $.145^{* * *}$ & & .026 \\
\hline
\end{tabular}




\begin{tabular}{|c|c|c|c|c|c|c|}
\hline 1860 & & Reference & & Reference & & Reference \\
\hline 1870 & & $-.160 * * *$ & & $-.227 * * *$ & & -.086 \\
\hline 1880 & & $-.365 * * *$ & & $-.389 * * *$ & & $-.333 * * *$ \\
\hline 1890 & & $-.256 * * *$ & & $-.254 * * *$ & & $-.251 * * *$ \\
\hline 1900 & & $-.214^{* * *}$ & & -.084 & & $-.384^{* * *}$ \\
\hline \multicolumn{7}{|l|}{ Decade Received } \\
\hline 1840 & $10.87 * * *$ & & $7.70 * *$ & & $11.62 * * *$ & \\
\hline 1850 & $3.86 * * *$ & & $4.94^{*}$ & & $3.82 * * *$ & \\
\hline 1860 & $3.88 * * *$ & & $3.39 * * *$ & & $4.13^{* * *}$ & \\
\hline 1870 & $1.30 * * *$ & & $2.52 * * *$ & & -.008 & \\
\hline 1880 & $-.268 * *$ & & -.015 & & $-.749 * * *$ & \\
\hline 1890 & $.340 * * *$ & & $.537 * * *$ & & .065 & \\
\hline 1900 & Reference & & Reference & & Reference & \\
\hline 1910 & $-.444 * * *$ & & $-.765 * * *$ & & -.108 & \\
\hline 1920 & $-1.83 * * *$ & & $-1.82 * * *$ & & $-1.71 * * *$ & \\
\hline \multicolumn{7}{|l|}{ Nativity } \\
\hline Northeast & & $.238 * * *$ & & $.446 * *$ & & $.209 * * *$ \\
\hline Middle Atlantic & & $-.131 * * *$ & & $-.144 * *$ & & $-.121 * * *$ \\
\hline Great Lakes & & Reference & & Reference & & Reference \\
\hline Plains & & $.077 *$ & & -.045 & & $.174 * * *$ \\
\hline Southeast & & $.327 * * *$ & & $.244 * * *$ & & $.460 * * *$ \\
\hline Southwest & & $1.15 * * *$ & & $.929 * * *$ & & $1.17 * * *$ \\
\hline Far West & & $.247 * * *$ & & $.408 * *$ & & $.327 * * *$ \\
\hline \multicolumn{7}{|l|}{ Occupations } \\
\hline White-Collar & $.398 *$ & $.179 * * *$ & $-.848 * *$ & .024 & $1.08 * * *$ & $.206 * * *$ \\
\hline Skilled & $1.12 * * *$ & $.155 * * *$ & .370 & $.120 * * *$ & $1.70 * * *$ & $.144 * * *$ \\
\hline Farmer & $2.36 * * *$ & $.618 * * *$ & $2.18 * * *$ & $.566 * * *$ & $2.60 * * *$ & $.619 * * *$ \\
\hline Unskilled & $1.86 * * *$ & $.281 * * *$ & $1.38 * * *$ & $.277 * * *$ & $2.42 * * *$ & $.240 * * *$ \\
\hline $\begin{array}{l}\text { No Occupation } \\
\text { Residence }\end{array}$ & Reference & Reference & Reference & Reference & Reference & Reference \\
\hline Arizona & .359 & & .359 & & $.940 * * *$ & \\
\hline Colorado & $2.92 * * *$ & & $2.92 * * *$ & & $3.46 * * *$ & \\
\hline Idaho & $1.26^{* *}$ & & $1.26 * *$ & & $1.48 * *$ & \\
\hline Kentucky & $-2.98 * * *$ & & $-2.98 * * *$ & & $-2.39 * * *$ & \\
\hline Missouri & $-4.22 * * *$ & & $-4.22 * * *$ & & $-3.84 * * *$ & \\
\hline New Mexico & $1.62 * * *$ & & $1.62 * * *$ & & $2.39 * * *$ & \\
\hline Oregon & $6.07 * * *$ & & $6.07 * * *$ & & $7.09 * * *$ & \\
\hline Pennsylvania & .167 & & .167 & & $1.59 * * *$ & \\
\hline Philadelphia & $-2.53 * * *$ & & $-2.53 * * *$ & & $-1.31 * * *$ & \\
\hline Tennessee & $2.38 * * *$ & & $2.38 * * *$ & & $3.13^{* * *}$ & \\
\hline Texas & Reference & Reference & Reference & Reference & Reference & Reference \\
\hline Environment & & & & & & \\
\hline Insolation & & $10.47 * * *$ & & $6.88 * * *$ & & $11.05 * * *$ \\
\hline Insolation $^{2}$ & & $-1.19 * * *$ & & $-.754 * * *$ & & $-1.27 * * *$ \\
\hline $\mathrm{N}$ & 141,407 & 141,407 & & 67,821 & 73,586 & 73,586 \\
\hline $\mathrm{R}^{2}$ & .3668 & .0999 & & .0978 & .3246 & .0891 \\
\hline
\end{tabular}


Source: See Table 1.

Notes: $* * *$ significant at .01; $* *$ significant at .05; * significant at .10. Height is measure in inches. The variable Insol represents incident solar radiation or the average daily amount of solar radiation or sunlight per day. Carson (2008b) and Carson (2009b).

Three general patterns emerge when analyzing $19^{\text {th }}$ century black and white weight. First, much has been written on the modern obesity epidemic (Flegal, 2009; Flegal, 2010; Flegal, 2012, Flegal, 2013; Cawley, 2011; Grossman and Macon, 2011); however, how weight varied over the $19^{\text {th }}$ century is less clear. Like stature and BMIs, black and white weights declined throughout the late $19^{\text {th }}$ and early $20^{\text {th }}$ centuries, and the decline in weight was greater than the decline in height. ${ }^{6}$ Between 1840 and 1900, average black statures increased by less than one percent, while average black weights decreased by five percent (Figure 3). Over the same period, average white statures were constant, while average white weight decreased by 10 percent, indicating that the weight relative to height decline overtime was greater for whites than for blacks. Much of the decline was related to nutrition, and any understanding of $19^{\text {th }}$ century weight variation must be made against the backdrop of nutritional adequacy. Throughout the late $19^{\text {th }}$ and early $20^{\text {th }}$ centuries, black and white net calorie allocations worsened (Figure 3; Floud et al. 2011, pp. 311-320; Putnam, 2000; Komlos, 1987, p. 909), and much of the decline was related to industrialization and the separation of food consumption from food production (Komlos, 1985; Komlos, 1987; Carson, 2008a, pp. 367-368). For whites, their disproportionate

$$
\begin{aligned}
{ }^{6} \mathrm{BMI} & =\frac{\mathrm{w}(\mathrm{K})}{\mathrm{h}(\mathrm{M})^{2}}=\mathrm{w} \mathrm{h}^{-2} . \Rightarrow \ln \mathrm{BMI}=\ln \mathrm{w}-2 \ln \mathrm{h} . \\
\varepsilon_{\mathrm{BMI}, \mathrm{w}} & =\frac{\% \Delta \mathrm{BMI}}{\% \Delta \mathrm{w}}=\frac{\mathrm{d} \ln \mathrm{BMI}}{\mathrm{d} \ln \mathrm{w}}=1 ; \quad \varepsilon_{\mathrm{BMI}, \mathrm{h}}=\frac{\% \Delta \mathrm{BMI}}{\% \Delta \mathrm{h}}=\frac{\mathrm{d} \ln \mathrm{BMI}}{\mathrm{d} \ln \mathrm{h}}=-2 .
\end{aligned}
$$


weight loss compared to blacks also reflects that with the end of slavery. Working class whites were, for the first time, exposed to increased competition with black (Woodward, 1951, p. 134; Carson, 2009c). In sum, throughout the late $19^{\text {th }}$ and early $20^{\text {th }}$ centuries, both black and white weights decreased more than the height decrease, and BMIs decreased because weights decreased more than heights increased (Figure 1; Carson, 2009a; Carson, 2012a).

Figure 3 Nineteenth Centuries US Black and White Statures and Weight

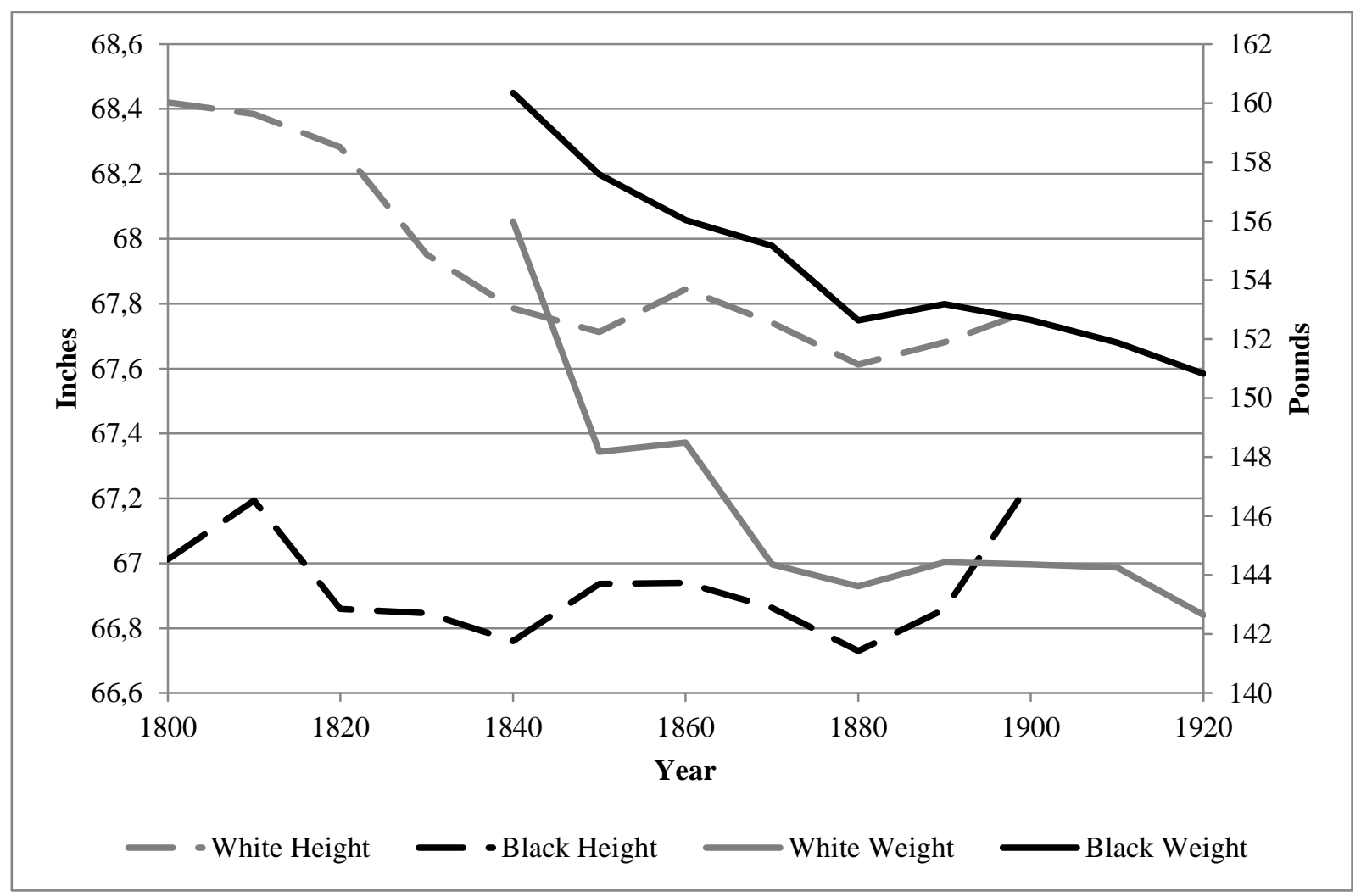

Source: See Table 3, Models 3 through 6.

Note: Average heights used for weight predictions are for 66.96 inches for blacks and 67.47 inches for whites.

Second, U.S. black and white weights were related to occupations, and like heights, farmers and unskilled workers had greater weights than workers in other occupations (Carson, 
2008a; Carson, 2012b). After controlling for height, greater farmer weights indicate that rural net nutrition was healthy compared to urban, industrialized living conditions (Komlos, 1987; Zahetmeyer, 2011; Green, 2012, p. 88). Black farmers’ average stature between 1840 and 1920 was .85 percent taller than all black workers, and black farmers' average weight was 1.45 percent greater than all black workers. White farmers’ stature was .92 percent taller than average white workers, and white farmers’ weight was 1.78 percent greater than average white workers, indicating that the white farmer biological advantage was greater than for blacks and workers in other occupations. Part of white farmer's weight advantage may have been due to white farmers' access to land and opportunity (Ransom and Sutch, 1977, pp. 80-83; Atack and Bateman, 1987, p. 93, Table 6.3). Part of heavier farmer and laborers weights were related to close proximity to rural diets and greater physical activity, which allowed farmers' access to nutrition before it was compromised when it was transported to market with the separation of food production from consumption (Fletcher, 1955, pp. 165, 195-202; Komlos, 1985; Carson, 2008a). For example, $19^{\text {th }}$ century Middle Atlantic dairy production had greater nutritional value in rural locations because shipping milk to markets in steel containers led to spoilage (Fletcher, 1955, p. 165; Carson 2008a, pp. 349-350). In 1840, most US agriculture was from owner-operated farms that primarily produced foodstuffs for household consumption. By 1900, US agriculture was transformed into a highly organized industry that supplied food for urban communities (Atack and Bateman, 1987; Fletcher, 1955, p. 165). Greater farmer and laborer weights were also related to physical activity because occupations that required greater physical activity decreased fat and increased muscle, and for the same tissue volume, muscle in heavier than fat (FAO/WHO, 1985; Fogel, 1997, p. 448). On the other hand, white-collar and skilled workers 
were typically urban residents and physically less active relative to calories consumed and did not put an additional weight.

Third, weight is related to residence, and $19^{\text {th }}$ century diets and weight varied regionally. Abundant food supplies, rural environments, and diets high in animal proteins were associated with heavier weights in the Deep South. For example, blacks from the Southwest were 1.4 percent taller than average black stature, and Tennessee black weight was 1.6 percent greater than average black weight. Whites from the Southwest were 1.7 percent taller than average white statures, and Tennessee white weight was 2.1 percent greater than average white weight, indicating that Southern white biological advantages were greater than for Southern blacks. Subsequently, there was a $19^{\text {th }}$ century net nutrition premium associated with Southern nativity and residence. Much of the regional weight variation was related to diet. Southern whites consumed more diverse and calorie abundant diets than other US whites, and white diets included pork, beef, corn, and Irish potatoes. Before the Civil War, the South was self-sufficient in food production and a net food exporter (Ransom and Sutch, 1977, p. 150), and heavier weights in the South demonstrates the benefits of close proximity to rural diets offset the calorie claims placed on diets by Southern disease climates (Crimmens and Condran, 1983). Alternatively, the Upper South, Middle Atlantic, and Northeast were agriculturally less productive, more urbanized, and had diets that were less protein based with a greater share of calories from breads and carbohydrates. The Middle Atlantic and Northeast were also more urban, which increased the relative price of nutrition (Komlos, 1987). Shergold (1982, pp. 185195) finds that Northeastern diets were high in grains, breads, and dairy products (Floud et al. 2011, p. 313; US Census, 1975, p. 1175). Westerners had heavier weights than elsewhere within the US but were shorter, indicating that Far Western settler's net cumulative health was 
substandard compared to other US regions, but once immigrants arrived in the West, their diets and net nutrition improved, and they put on weight (Green, 2012, p. 88). America’s Far West had only recently been settled, and there was greater access to animal proteins from domesticated animals and feral game. Because of its recent settlement, individuals in the Far West may have also been more physically active than workers in other locations, and greater physical activity is associated with heavier weights.

Other patterns are consistent with expectations. Height was positively related with weight but inversely related with BMI, indicating that although individuals with taller statures had larger physical frames and dimensions to distribute weight, taller statures were inversely related with BMIs (Table 3; Carson, 2009a; Carson, 2012a). After controlling for height, black and mulatto weights were five and three percent greater than average white weight. A considerable amount of work demonstrates that mulattos were taller than darker complexioned blacks; however, blacks had greater BMIs than mulattos, who, in turn, had greater BMIs than whites. Blacks have greater percent muscle mass than whites, and muscle is heavier than fat (Flegal et al., 2010, p. 240; Flegal et al., 2009, p. 507; Aloia et al., 1999, p. 116; Evans et al., 2006).

Modern health studies also illustrate the relationship between weight change and age. For example, even among the most physically active modern males, weight gain increases with age and may occur because diets contain greater fat content or because physical activity decreases with age (Williams and Wood, 2006, p. 545; Sherwood et al., 2000, pp. 398-401). However, plausible explanation for black and white weight gain at older ages for both historical and modern populations relates to testosterone, human growth hormone, and metabolism, which are important hormonal weight regulators, and each decreases with age (Rudman et al. 1990, pp. 
1 and 5). With decreased hormones, metabolisms decline and central adiposity increases (Rosmund and Björntorp, 1998). This historical weight-age finding is important because it illustrates that weight gain at older ages existed before the rise of the modern obesity epidemic and cannot be attributed to the same factors associated with the modern obesity epidemic. As a result, like height, $19^{\text {th }}$ century weight was related with a complex set of relationships between observation period, socioeconomic status, residence, ethnicity, and stature, and weight accumulation occurs at older ages with hormonal changes associated with aging.

\section{Explaining the $19^{\text {th }}$ Century Black and White Weight Differential}

To more fully account for the source of the black-white weight differential, a BlinderOaxaca weight decomposition is constructed for weight. A Blinder-Oaxaca decomposition is a statistical technique used to separate sample dependent variable differences that are due to average characteristics and returns to characteristics (Oaxaca, 1973). If differences are due to average characteristics, characteristic differences between the two populations accounts for differences between populations. However, if differences are due to returns to characteristics, market and institutional differences between the populations accounts for the differences between the black and white sub-samples.

Let $\mathrm{W}_{\mathrm{b}}$ and $\mathrm{W}_{\mathrm{w}}$ represent black and white weights, respectively; $\alpha_{\mathrm{b}}$ and $\alpha_{\mathrm{w}}$ are the autonomous weight components associated with black and white weights; $\beta_{\mathrm{b}}$ and $\beta_{\mathrm{w}}$ are the black and white weight returns associated with specific weight enhancing characteristics, such as age and occupation. $\mathrm{X}_{\mathrm{b}}$ and $\mathrm{X}_{\mathrm{w}}$ are black and white characteristic matrices, and black weights are assumed to be the base structure. Weight models by race are constructed by regressing black and white weights on demographic, residential, socioeconomic status, and observation period.

$$
\text { Black Weight function: } \quad \mathrm{W}_{\mathrm{b}}=\alpha_{\mathrm{b}}+\beta_{\mathrm{b}} \mathrm{X}_{\mathrm{b}}
$$




$$
\text { White Weight function: } \quad \mathrm{W}_{\mathrm{w}}=\alpha_{\mathrm{w}}+\beta_{\mathrm{w}} \mathrm{X}_{\mathrm{w}}
$$

The black and white weight gap is the difference between their average characteristics and returns to characteristics.

$$
\Delta \mathrm{W}=\mathrm{W}_{\mathrm{b}}-\mathrm{W}_{\mathrm{w}}=\alpha_{\mathrm{b}}+\beta_{\mathrm{b}} \mathrm{X}_{\mathrm{b}}-\alpha_{\mathrm{w}}-\beta_{\mathrm{w}} \mathrm{X}_{\mathrm{w}}
$$

Adding and subtracting $\beta_{\mathrm{w}} \mathrm{X}_{\mathrm{b}}$ to the right and side of the equation and collecting like terms leads

to

$$
\Delta W=W_{b}-W_{w}=\left(\alpha_{b}-\alpha_{w}\right)+\left(\beta_{b}-\beta_{w}\right) X_{b}+\beta_{w}\left(X_{b}-X_{w}\right)
$$

The first right hand side element, $\left(\alpha_{b}-\alpha_{w}\right)$, is the part of the weight gap due to nonidentifiable sources, such as greater percent muscle mass and greater bone mineral density that favored blacks (Barondess et al., 1997; Wagner and Heyward, 2000). Differences in the intercepts also exist because blacks and whites had different access to diets and disease environments. The second right hand-side element, $\left(\beta_{b}-\beta_{w}\right) X_{b}$, is the component of the weight gap due to characteristic returns. The third right-hand side element, $\beta_{w}\left(X_{b}-X_{w}\right)$, is the part of the weight gap due to differences in average characteristics and is unknown because whites probably had characteristics associated with greater weight values, but blacks were shorter. 
Table 4, Nineteenth Century National Weight Black and White Decomposition

\begin{tabular}{l|cccc}
\hline Levels & $\left(\beta_{b}-\beta_{w}\right) \bar{X}_{b}$ & $\left(\bar{X}_{b}-\bar{X}_{w}\right) \beta_{w}$ & $\left(\beta_{b}-\beta_{w}\right) \bar{X}_{w}$ & $\left(\bar{X}_{b}-\bar{X}_{w}\right) \beta_{b}$ \\
\hline & Returns to & Mean & Returns to & Mean \\
& Characteristics & Characteristics & Characteristics & Characteristics \\
Sum & 7.40 & -2.55 & 6.63 & -1.78 \\
Total & & 4.85 & & 4.85 \\
Proportion & & & & \\
Intercept & 3.88 & -.373 & -1.88 & -.360 \\
Height & -1.80 & -.175 & -.223 & -.230 \\
Ages & -.279 & -.020 & .067 & -.012 \\
Decade & .074 & .047 & -.342 & .198 \\
Residence & -.190 & -.005 & -.201 & .036 \\
Occupation & -.160 & -.525 & 1.37 & -.367 \\
Sum & 1.53 & 1 & & 1 \\
Total & & & &
\end{tabular}

Source: See Tables 1 and 3.

Using coefficients from the weight regressions (Tables 3 and 6, Model 1), the weight decomposition indicates that the majority of heavier black weights were from non-identifiable characteristics, such as greater bone mineral density and lean muscle mass (Table 4; Barondess et al., 1997; Wagner and Hayward, 2000; Flegal et al. 2010, p. 240; Flegal et al. 2009, p. 507; Fernandez et al. 2003; Aloia et al, 1999, p. 116; Evans et al. 2006). However, the majority of the weight gap due to observable characteristics was associated with stature, and $19^{\text {th }}$ century whites had greater weight returns associated with height than blacks, indicating that white stature returns extended to weights. Whites also had greater weight returns than blacks for age, residence, and occupations. Other observable characteristics did not contribute to the blackwhite weight gap. In sum, the greatest share of the black-white weight gap was due to nonidentifiable characteristics, such as differences in lean muscle mass and greater bone mineral 
density, and the white stature advantage also extended to white weighst (Barondess et al., 1997, pp. 967-971; Flegal et al., 2013, p. 240).

\section{Conclusion}

When traditional methods to measure wealth are unavailable, the use of height and BMIs are now well accepted measures for economic welfare. Stature measures a population's net cumulative nutrition, while BMIs are frequently interpreted as representing a population's net current nutrition. However, as the ratio of weight to height, BMI differences over time and across residence are problematic because BMIs increase with weight and decrease with stature, and $19^{\text {th }}$ century statures and weight varied both over time and by residence. As a result, weight may be a better measure for net current nutrition than BMIs because weight is not constructed as the ratio of net cumulative to net current nutrition variables. Nevertheless, BMIs are important measures for obesity because they allow reasonable classifications for weight relative to height.

Like height and BMI, black and white weights decreased throughout the $19^{\text {th }}$ century, and there is no sign that average weight among the working class increased prior to the modern obesity epidemic. Both black and white weights decreased throughout the late $19^{\text {th }}$ and early $20^{\text {th }}$ centuries, and white weight relative to height declines were greater than for blacks, indicating that net current nutrition declines may have been greater for whites than blacks because free white labor was integrated with the market, and with emancipation, lower class whites had to compete with working class blacks. Farmers and unskilled workers were taller and had greater BMIs than white-collar and skilled workers, and after controlling for height, farmers and unskilled workers had greater average weight than workers in other occupations. Weight was also related with $19^{\text {th }}$ century residence, and working class men from the Northeast and Middle Atlantic had lower weights and shorter statures than individuals from other US regions. 
Southerners had taller statures and greater weight than individuals with other nativities, indicating that close proximity to agricultural production and rural diets were associated with taller statures and heavier weights.

There is also a long-standing debate on the net interaction of diets versus disease in the biological well-thinking of $19^{\text {th }}$ century Americans. The regional weight comparison with heights and BMIs indicates that Southern rural net current and cumulative nutritional conditions had a greater influence on weight and height than disease because the South had more virulent disease environments; however, Southerners had taller statures, greater BMIs, and heavier weights than elsewhere within the United States, indicating that net nutritional conditions were better in the South. Results reported here also have important implications for the modern obesity epidemic, and weights increased with age for both modern and historical populations, indicating that male weights increase with age and does not depend on factors associated with the modern obesity epidemic. 


\section{References}

Aloia, J.F., A. Vaswani, R. Ma, and E. Flaster. 1999. Comparison of body composition in black and white premenopausal women. Journal Laboratory Clinical Medicine 129: 294-299.

Atack, Jeremy and Fred Bateman, 1987, To Their Own Soil: Agriculture in the Antebellum North. Ames, Iowa: Iowa State University Press.

Atlas, Scott. 2011. In Excellent Health: Setting the Record Straight on America's Health Care. Hoover Institution Press.

Auld, Christopher and Paul Grootendorst. (2011). “Challenges for Causal Inference in Obesity Research.” In John Cawley’s The Oxford Handbook of the Social Science of Obesity. Oxford: Oxford University Press, pp. 237-256.

Ball, Kylie and David Crawford. 2005. "Socioeconomic Status and Weight in Adults: A Review.” Social Science \& Medicine. 60. pp. 1987-2010.

Barondess, D. A., D. A. Nelson, and S. E. Schlaen, 1997. Whole body bone, fat and lean mass in black and white men. Journal of Bone and Mineral Research 12: 967-971.

Baum, Christopher, and Christopher Ruhm. 2009. “Age, Socioeconomic Status, and Obesity Growth.” Journal of Health Economics. 28: 635-648.

Carson, Scott Alan. (2005) “The Biological Standard of Living in 19th-Century Mexico and in the American West,” Economics and Human Biology, Volume 3(3), pp. 405-419.

Carson, Scott Alan. (2007) "Mexican Body Mass Index Values in the $19^{\text {th }}$ Century American West,” Economics and Human Biology, Volume, 5(1), 37-47.

Carson, Scott Alan. (2008a) "Health during Industrialization: Evidence from the $19^{\text {th }}$ Century Pennsylvania State Prison System,” Social Science History. Volume 32(3). pp. 347-372. 
Carson, Scott Alan. (2008b) “The Effect of Geography and Vitamin D on African-American Stature in the $19^{\text {th }}$ Century: Evidence from Prison Records,” Journal of Economic History, 68(3), pp. 812-830.

Carson, Scott Alan. (2009a) "Racial Differences in Body-Mass Indices of Men Imprisoned in $19^{\text {th }}$ Century Texas” Economics and Human Biology 7, pp. 121-127.

Carson Scott Alan. (2009b). “Geography, Insolation, and Vitamin D in $19^{\text {th }}$ Century US AfricanAmerican and White Statures.” Explorations in Economic History 46:149-159.

Carson, Scott Alan. (2009c) “African-American and White Inequality in the $19^{\text {th }}$ Century American South: A Biological Comparison,” 22(3), Journal of Population Economics. pp. 757-772.

Carson, Scott Alan. (2011), “Height of Female Americans in the $19^{\text {th }}$ century and the Antebellum Puzzle,” Economics and Human Biology 9, pp. 157-164.

Carson, Scott Alan. (2012a), “Nineteenth Century Race, Body Mass, and Industrialization: Evidence from American Prisons,” Journal of Interdisciplinary History. pp. 371-391.

Carson, Scott Alan. (2012b). “A Quantile Approach to the Demographic, Residential, and Socioeconomic Effects on 19th Century African-American Body Mass Index Values” Cliometrica. 6(2), pp. 193-209.

Carson, Scott Alan. (2013). “Demographic, Residential, and Socioeconomic Effects on the Distribution of $19^{\text {th }}$ Century US Female Statures.” Feminist Economics.

Carson, Scott Alan (2013). “Biological Conditions and Economic Development: Westward Expansion and Health in Late Nineteenth and Early Twentieth Century Montana.” Journal of the Historical Society, 13(1): 51-68.

Case, Anne and Christina Paxson (2008a). “Height, Health, and Cognitive Function at Older 
Ages.” American Economic Review 98, 2, pp. 463-467.

Case, Anne and Christina Paxson (2008b). "Stature and Status: Height, Ability, and Labor Market Outcomes.” Journal of Political Economy 116, 3, pp. 499-532.

Cawley, John (Ed.) The Oxford Handbook of the Social Science of Obesity. Oxford University Press: Oxford

Cawley, John and Joshua Prince. "Outcomes in a Program that Offers Financial Rewards for Weight Loss.” In Michael Grossman and Naci Macon (eds.) Economic Aspects of Obesity. Chicago: University of Chicago Press, pp. 91-126.

Costa, Dora and Richard Steckel (1997). "Long-Term Trends in US Health, Welfare, and Economic Growth.” In Health and Welfare during Industrialization. Richard Steckel and Roderick Floud (Eds.). Chicago: University of Chicago Press.

Crimmens, E. and G. A. Condran. "Mortality Variation in U.S. Cities in 1900: A Two Level Explanation by Cause of Death and Underlying Factors." Social Science History. 7, no. 1 (1983): 31-59.

Deaton, Angus. 2008 "Height, Health, and Inequality: the Distribution of Adult Height in India.” American Economic Review 98, 2, pp. 468-474.

Eckel, Robert H., Scott M. Grundy, and Paul Z Zimmet. 2005 “The Metabolic Syndrome.” The Lancet 365, pp. 1415-1428.

Einkelstein, Eric and Hae Kyung Yang. 2011. “Obesity and Medical Costs.” in Cawley, John (Ed.) The Oxford Handbook of the Social Science of Obesity. Oxford University Press: Oxford, pp. 495-501.

Evans, E. M., D. A. Rowe, S. C. Racette, K. M. Ross, and E. Mcauley. 2006. Is the current BMI obesity classification appropriate for black and white post-Menopausal women? 
International Journal of Obesity 30: 837-843.

Fernandez J, Heo M, Heymsfield S, Pierson R, Pi-Sunyer X, Wang Z, Wang J, Hayes M, Allison D, Gallagher D (2003) Body composition and dual energy x-ray absoptiometry in black compared to white women. American Journal of Clinical Nutrition 10: 114-119

Flegal, K., J. Shepherd, A. Looker, B. Graubard, L. Borrud, C. Ogden, T. Harris, J. Evenhart, and N. Schenker. 2009. Comparisons of percentage body fat, body mass index, waist circumference, and waist-stature in adults. American Journal of Clinical Nutrition 89: 500-508.

Flegal K, Carroll M, Ogden C, Prevalence and trends in obesity among US adults, 1999-2008. Journal of the American Medical Society. 2010; 303:235-241.

Flegal K, Carroll M, Kit B, Ogden C. Prevalence of obesity and trends in the distribution of body mass index among US adults, 1999-2010. Journal of the American Medical Association. 2012; 307:491-497.

Flegal, Katherine, Brain Kit, Heather Orpana, and Barry Graubard. (2013). “Association of AllCause Mortality with Overweight and Obesity Using Standard Body Mass Index Categories.” Journal of the American Medical Association 309(1), 71-82.

Fletcher, Steven Whitcomb, Pennsylvania Agriculture and Country Like, 1840-1940. Harrisburg, PA: Pennsylvania Historical and Museum Commission, 1955.

Floud, Roderick, Robert Fogel, Bernard Harris, Sok Chul Hong. 2011. The Changing Body: Health, Nutrition, and Human Development. Cambridge: Cambridge University Press.

Fogel, Robert, Stanley L. Engerman, James Trussell, Rodrick Floud, Clayne Pope, and Larry Wimmer. 1978. "The Economics of Mortality in North American, 1650-1910: A 
Description of a Research Project.” Historical Methods 11(2), pp. 75-109.

Fogel, Robert W. (1993) "New Sources and New Technique for the Study of Secular Trends in Nutritional Status, Health, Mortality, and the Process of Aging," Historical Methods.

Fogel, Robert W. "Economic Growth, Population Theory and Physiology: The Bearing of Long-Term Processes on the Making of Economic Policy,” American Economic Review 84(3), 1994, pp. 369-395.

Fogel, Robert W. 1997. "New Findings on Secular Trends in Nutrition and Mortlaity: some Implications for Population Theory. In:Resenzweig, M.R., Stark, O. (Eds.) Handbook of Population and Family Economics. Elsevier, Amsterdam and New York.

FAO/WHO/UNU Expert Consultation, Technical Report Series No. 724, World Health Organization, Geneva.

Giovannucchi, Edward, Alberto Ascherio, Eric Riff, Graham Colditz, Mier Stampfour, and Walter Willett. 1995. "Physical Activity, Obesity, and Risk for Colon Cancer and Anemia in Men.” Journal of National Cancer Institute 84(2) pp. 91-98.

Goldman, Dana, Darius Lakdawalla, and Yuhui Zheng. 2011. “Food Prices and Dynamics of Body Weight.” In Michael Grossman and Naci Macon (eds.) Economic Aspects of Obesity. Chicago: University of Chicago Press, pp. 65-90.

Green, Rayna. 2012. “Public Histories of Food.” In Jeffrey Pilcher (Ed.) The Oxford Handbook of Food History. Oxford: Oxford University Press. pp. 81-98.

Grossman, Michael and Naci Macon 2011. Economic Aspects of Obesity. Chicago: University of Chicago Press.

Haines, Michael R. (2004). “Growing Incomes, Shrinking People—Can Economic Development be Hazardous to Your Health?” Social Science History. 28, 2 pp. 249-270. 
Henderson, R. Max (2005). “The Bigger the Healthier: Are the Limits of BMI Risk Changing over Tim?” Economics and Human Biology 3, 3 pp. 339-366.

Herbert,P., Richards-Edwards, J., Manson, J.A., Ridker, P., Cook, N., O’Conner, G., Buring, J., Hennekens, C., 1993. Height and incidence of cardiovascular disease in male physicians. Circulation 88, 1437-1443.

Hirshchi, Travis and Michaeal Gottfredson. (1983). “Age and Explanation of Crime.” American Journal of Sociology 89(3), pp. 552-584.

Kaaks, p., A. Lakonova, and M.S. Kurzer. 2002. “Obesity, Endogenous Hormones, and Endometrial Cancer Risk.” Cancer, Epidemiology, Biomarkers, and Prevention 11, pp. 1531-1543.

Koch, D., 2011. Waaler revisited: the anthropometrics of mortality. Economics and Human Biology 9, 106-117.

Komlos, John. 1985. "Stature and Nutrition in the Hapsburg Monarchy: the Standard of Living and Economic Development in the Eighteenth Century.” American Historical Review 90(5) 1149-1161.

Komlos, J., 1987. "The Height and Weight of West Point Cadets: Dietary Change in Antebellum America.” Journal of Economic History 47, 897-927.

Komlos, John and Peter Coclanis (1995). "Nutrition and Economic Development in Post Reconstruction South Carolina: An Antropometric Approach.” Social Science Journal 19, 1, pp. 91-115.

Komlos, J., Brabec, M., 2011, The trend of BMI values of US adults on deciles, birth cohorts 1882-1986 stratified by gender and ethnicity. Economics and Human Biology 9, 234250. 
Ligigibeli, Jennifer. 2011. “Obesity and Cancer.” Oncology 25, 11.

Luke, A., X. Guo, A. A.Adeyomo, R. Wilks, T.Forrestor, W. W. .Lowe, A.G.Comuzzie, L. J. Martin, (2001). “Heritability of obesity-related traits among Nigerians, Jamaicans and US black people.” International Journal of Obesity Rel. Meta. Disease 25: 10341041.

Margo, Robert and Richard Steckel. "Heights of American Slaves: New Evidence on Nutrition and Health.” Social Science History 6, no. 4 (Fall, 1982): 516-538.

Margo, Robert and Richard Steckel. 1992, “The Nutrition and Health of Slaves and antebellum Southern whites.” in Without Consent or Contract: Conditions of Slave Life and the Transition to Freedom, edited by R. W. Fogel and S. L. Engerman, New York: Norton, 508-521.

Must, Aviva, Jennifer Spandano, Eugenie Coakley, Alison Field, Graham Colditz, and William Dietz. (1999). “The Disease Burden Associated with Overweight and Obesity.” Journal of the American Medical Association 282(16): pp. 1523-1529.

Oaxaca RL (1973) Male female wage differentials in urban labor markets. International Economic Review 14: 693-709

Putnam, Judy 2000. “Major Trends in U.S. Food Supply, 1909-1999.” Food Review. 23(1), pp. 8-15).

Ransom Roger and Richard Sutch. One Kind of Freedom: the Economic Consequences of Emancipation. Cambridge: Cambridge University Press, 1977.

Ravelli, Gian-Paolo, Zena Stein, and Mervyn Susser. 1976. “ Obesity in Young Men after Famine Exposure in Utero and Early Infancy.” The New England Journal of Medicine 295, 349-353. 
Roberto, Christina and Kelly Brownell (2011). “The Imperative of Changing Public Policy to Address Obesity.” in Cawley, John (Ed.) The Oxford Handbook of the Social Science of Obesity. Oxford University Press: Oxford, pp. 587-608.

Rosmund, R. and Björntorp, P. 1998. “The interactions between hypothalamic-pituitary-adrenal axis activity, testosterone, insulin-like growth factor I and abdominal obesity with metabolism and blood pressure in men.” International Journal of Obesity Related to Metobolic Disorders 22(12), pp. 1184-1196.

Rudman, Daniel, Alex Feller, Hoskote Hagraj, Gregary Gergans, Pardee Lalitha, Allen Goldberg, Robert S. Schlenker, Lester Cohn, Inge Rudman and Dale Mattson 1990. "Effects of Human Growth Hormone in Men Over 60 Years Old.” The New England Journal of Medicine 323(1), pp. 1-6.

Sherwood, NE, RW Jeffery, SA French, PJ Hannan, and DM Murray. (2000). "Predictors of Weight Gain in Pound of Prevention Study.” International Journal of Obesity. 24, pp. 395-403.

Snowden, David, Ronald Phillips, and Warren Choi. 1984. "Diet, Obesity, and Risk of Fatal Prostate Cancer.” American Journal of Epidemiology 120(2) pp. 244-250.

Steckel, Richard, 1979, “Slave Height Profiles from Coastwise Manifests,” Explorations in Economic History 16, pp. 363-380.

Stauss, J., and D. Thomas [1998], “Health, Nutrition, and Economic Development,” Journal of Economic Literature, 36, 766-817.

Sutch, Richard 1977. “The Care and Feeding of Slaves.” In: David, Paul, Hurbert Gutman, Richard Sutch, Peter Temin, and Gavin Wright. Reckoning with Slavery. Oxford: Oxford University Press, pp. 231-301. 
Vidal, J. 2002. "Updated Review on the Benefits on Weight Loss.” International Journal of Obesity 26 (Suppl 4): S25-S28.

Waaler, H. T. 1984. Height, weight and mortality: the Norwegian experience. Acta Medica Scandinavia 679: 1-51.

Wagner, D. R. and V. H.Heyward, 2000. Measures of composition in blacks and whites: a comparative review. American Journal of Clinical Nutrition 71: 1392-1402.

Wahl, Jenny Bourne, 1996, “The Jurisprudence of American Slave Sales,” The Journal of Economic History, 56(1), pp. 143-169.

Wahl, Jenny Bourne, 1997, "Legal Constraints on Slave Masters: the Problem of Social Cost,” The American Journal of Legal History, 1997, pp. 1-24.

Williams, PT and PD Wood. (2006). "The Effects of Changing Exercise Levels on Weight and Age-Related Weight Gain.” International Journal of Obesity 30, pp. 543-551.

Winward, C. Vann. (1951). Origins of the New South, 1877-1913. Louisiana State University Press.

Zehetmayer, Matthias. (2011). “The Continuation of the Antebellum Puzzle: Stature in the US, 1847-1894.” European Review of Economic History. 